Vol 1. No 1. Februari 2017

\title{
Pertumbuhan Planlet Stroberi (Fragaria ananassa D) Var. Dorit pada Beberapa Variasi Media Modifikasi In Vitro di Balai Penelitian Jeruk dan Buah Subtropika (BALITJESTRO)
}

\author{
Vida Nofrianinda1 ${ }^{1}$, Farida Yulianti², Eva Agustina $^{3}$ \\ 1,3 Program Studi Biologi UIN Sunan Ampel Surabaya, \\ 2Balai Penelitian Jeruk dan Buah Subtropika, Junrejo, Batu. \\ *Email: nofrianinda@gmail.com
}

\begin{abstract}
ABSTRAK
Stroberi (Vragaria ananassa Dutch) Var. Dorit merupakan buah yang populer di masyarakat dunia dengan ciri khas rasa buahnya yang asam manis dan segar. Penyediaan benih stroberi selama ini dilakukan secara konvensional dengan menggunakan stolon, sehingga volume perbanyakan relatif lebih sedikit dan tidak bebas penyakit. Oleh karena itu diperlukan metode kultur jaringan untuk budidaya stroberi. Kultur jaringan tanaman merupakan suatu teknik pengisolasian dan pemeliharaan sel atau potongan jaringan tanaman yang ditumbuhkan pada media buatan yang sesuai dan dalam keadaan aseptik. Medium yang dipergunakan pada kultur in vitro tumbuhan ada bermacam-macam. Medium yang digunakan dalam percobaan ini yaitu media MP yang merupakan kombinasi dari larutan MS (Murashige and skoog) dan pupuk cair. Dalam hal ini pupuk yang digunakan merupakan produk dari Balitjestro yang tentunya mengandung beberapa nutrisi dengan konsentrasi yang tepat untuk petumbuhan tanaman. Percobaan ini dilakukan untuk mengidentifikasi pengaruh berbagai modifikasi media MP serta mengidentifikasi konsentrasi kombinasi media MP yang sesuai terhadap pertumbuhan stroberi varietas dorit. Percobaan ini menggunakan Rancangan Acak Kelompok (RAK) dengan perlakuan MP1: MS 25\% + pupuk 75\%, MP2: MS 50\% + pupuk 50\%, MP3: MS 75\% + pupuk 25\%, MP4: pupuk 100\%, Percobaan di ulang 5x, sehingga diperlukan 20 unit percobaan. Setiap unit percobaan ditanam 5 planlet. Pertumbuhan tanaman stroberi varietas dorit yang ditanam pada media MP1, MP2, MP3 dan MP4 menunjukkan pengaruh perbedaan yang signifikan terhadap pertumbuhan akar, pertumbuhan tunas dan pertambahan jumlah daun. Tanaman tersebut menunjukkan respon pertumbuhan yang paling cepat pada media MP3 karena mengandung konsentrasi larutan MS lebih banyak sehingga jumlah nitrogen yang dibutuhkan untuk pertumbuhan lebih tercukupi.
\end{abstract}

Kata Kunci: Stroberi Dorit, Media MS, Pupuk Cair, Nitrogen, Pertumbuhan Akar, Petumbuhan Tunas, Pertambahan Jumlah Daun.

\section{PENDAHULUAN}

Stroberi merupakan suatu komoditas buah sub tropis yang sangat potensial untuk dikembangkan di Indonesia, terutama di dataran tinggi. Buah stroberi banyak mengandung bahan fitokimia terutama senyawa fenolik yang bermanfaat bagi kesehatan. Spesies yang paling umum ditanam dan dijual adalah hasil persilangan Fragaria $\times$ ananassa (Tim Karya Tani Mandiri, 2010). Persilangan kedua jenis tersebut dilakukan pada tahun 1750 (Budiman dan Saraswati, 2006). Tanaman stroberi (Fragaria Ananassa. Dutch) varietas 
dorit merupakan varietas persilangan antara

Dover A dan Nurit, yang menghasilkan varietas dengan bunga sepanjang bulan daripada varietas stroberi lainnya. Varietas dorit memproduksi buah mulai bulan November sampai akhir musim semi (Hannum 2004).

Menurut Badan Pusat Statistik (2011), produksi stroberi di Indonesia pada tahun 2011 mencapai 24.846 ton dan presentase perkembangan produksinya mencapai $29,87 \%$ pertahun. Salah satu varietas yang dikembangkan di Indonesia adalah Dorit yang memiliki warna buah matang merah menyala, ukuran buahnya besar (panjang 43$50 \mathrm{~mm}$, lebar 30-36 $\mathrm{mm}$ ) dan rasanya manis (E. Iszak, and S. Izhar., 1992). Namun, perkembangbiakan stroberi secara konvensional menimbulkan banyak infeksi penyakit dan tidak cukup untuk memenuhi kebutuhan bibit komersial (A. Mozafari, M. Gerdakaneh, 2012).

Permasalahan stroberi di Indonesia adalah ketersediaan benih berkualitas dan bebas penyakit. Penyediaan benih stroberi selama ini dilakukan secara konvensional dengan menggunakan stolon. Kelemahannya adalah volume perbanyakan relatif lebih sedikit dan tidak bebas penyakit karena infeksi patogen endogenus yang ditularkan dari tanaman induk. Bibit tertular patogen ini yang menyebabkan kualitas dan kuantitas produksi buah semakin menurun setelah tiga periode penanaman (Zebrowska 2004).

Salah satu pemecahan masalah mengenai ketersediaan bibit berkualitas yaitu dengan mengupayakan perbaikan genetika benih atau bibit domestik.. Selama ini bibit yang ada adalah pengembangan dari impor tahun 2004 yang bisa dipastikan kualitasnya semakin menurun, dengan buah yang semakin jarang dan mengecil. Oleh karena itu diperlukan metode kultur jaringan untuk budidaya stroberi (A.M. Shohael, 2008).

Kultur jaringan adalah suatu metode untuk mengisolasi bagian dari tanaman seperti protoplasma, sel, jaringan, organ serta menumbuhkannya dalam kondisi aseptik sehingga bgaian-bagian tersebut dapat memperbanyak diri dan beregenerasi menjadi tanaman utuh kembali (Gunawan, 1995). Sel, jaringan dan organ tanaman ditumbuhkan dalam suatu lingkungan yang terkendali dan dalam keadaan aseptik atau bebas mikroorganisme (Santoso dan Nursandi, 2003). Perbanyakan tanaman melalui kultur jaringan sangat berbeda dibandingkan dengan perbanyakan secara konvensional karena perbanyakan melalui kultur jaringan memungkinkan perbanyakan tanaman dalam skala besar dengan waktu yang relatif lebih cepat (Santoso dan Nursandi, 2002).

Teknik kultur jaringan menekankan linkungan yang sesuai agar eksplan dpat tumbuh dan berkembang. Lingkungan yang sesuai akan terpenuhi bila media yang dipilih mempertimbangkan segala sesuau yang dibutuhkan oleh tanaman. Salah satu faktor penentu keberhasilan pelaksanaan kerja kultur jaringan adalah pemberian nutrisi 
dalam jumlah dan perbandingan yang benar pada medium kultur. Medium yang dipergunakan pada kultur in vitro tumbuhan ada bermacam-macam. Pemilihan medium tergantung pada jenis tanaman yang digunakan, selera, tujuan serta perhitungan masing-masing peneliti (George Z Sherrington, 1984 Dalam Indrianto, A, 2002).

Medium yang digunakan dalam percobaan ini yaitu media MP yang merupakan kombinasi dari larutan MS (Murashige and skoog) dan pupuk cair. Dalam hal ini pupuk yang digunakan merupakan produk dari Balitjestro yang tentunya mengandung beberapa nutrisi dengan konsentrasi yang tepat untuk petumbuhan tanaman. Namun belum ditemukan konsentrasi kombinasi yang tepat antara media MS dan pupuk serta pengaruhnya terhadap pertumbuhan dan perkembangan planlet stroberi. Oleh karena itu penelitian ini dilakukan dengan tujuan utnuk mengidentifikasi pengaruh berbagai modifikasi media MP terhadap pertumbuhan dan perkembangan tanaman serta mengidentifikasi konsentrasi kombinasi media MP yang sesuai terhadap pertumbuhan stroberi varietas dorit.

\section{METODE}

Penelitian ini dilaksanakan pada bulan Januari hingga Februari 2016 di Balai Penelitian Tanaman Jeruk dan Buah Subtropika (Balitjestro), Jl. Raya Tlekung no. 1, Junrejo, Kota Batu, Jawa Timur.
Alat yang digunakan yaitu LAFC (Laminar Air Flow Cabinet), autoklaf, neraca analitik, pH meter, kompor gas, stirer, magnetic stirer + hiter, botol kultur, botol alkohol, gelas beker, labu ukur, pipet mikro, spatula, pinset, scalpel, selotip, plastic wrap, spidol, silet, cawan petri, korek api dan bunsen.

Bahan yang digunakan yaitu planlet stroberi varietas dorit, MS (nitrat, sulfat, fosfat, halida, ferrum), pupuk, vitamin, myo inositol, gula, aquades, NAA, Agar, NaOH, HCL, antibiotik, alkohol 70\% dan alkohol 69\%.

\section{Persiapan Planlet}

Planlet yang digunakan berupa planlet in vitro stroberi varietas Dorit (Fragaria ananassa var. Dorit) umur \pm 75 hari. Planlet diperoleh dari laboratorium Kultur Jaringan Balitjestro yang sebelumnya telah dikultur dalam media MS.

\section{Pembuatan Media}

Media kultur yang digunakan adalah media MP yang merupakan kombinasi dari larutan MS dengan penambahan larutan pupuk. Langkah pertama yaitu dituang masing-masing larutan MS dan pupuk dengan perbadingan konsentrasi:

MP1 : MS 25\% + pupuk 75\%

MP2 : MS 50\% + pupuk 50\%

MP3 : MS 75\% + pupuk 25\%

MP4 : pupuk 100\%

Keempat kombinasi campuran tersebut masing-masing diberi penambahan vitamin sebanyak $2 \mathrm{ml} / \mathrm{L}$, myo inositol dan akuades, kemudian di stirrer hingga homogen. Setelah itu disesuaikan $\mathrm{pH}$ nya hingga 5,8. Setelah $\mathrm{pH}$ 
sesuai, ditambahkan serbuk agar $10 \mathrm{~g} / \mathrm{L}$ lalu dididihkan menggunakan kompor gas dan diaduk hingga agar-agar larut dan tercampur rata kemudian dibagi media sekitar $20 \mathrm{ml} /$ botol ke dalam botol kultur dalam keadaan masih cair. Botol kultur ditutup rapat dengan penutup plastik, diberi label sesuai perlakuan (MP1, MP2, MP3, dan MP4) dan diautoklaf pada suhu $121^{\circ} \mathrm{C}$ selama 15 menit.

\section{Sterilisasi}

Alat-alat dissecting set dan glassware yang akan digunakan dicuci terlebih dahulu, dikeringkan kemudian dibungkus dengan plastik. Selanjutnya alat-alat disterilisasi didalam autoklaf pada suhu $121^{\circ} \mathrm{C}$ selama 15 menit. Bagian dalam laminar air flow disemprot dengan alkohol 70\%. Kemudian lampu UV dinyalakan selama 1jam. Sebelum dan selama pemakaian, blower dalam laminar air flow harus dinyalakan. Kemudian sebelum melakukan pekerjaan, dilakukan sterilisasi dengan alkohol 70\% pada kedua telapak tangan, botol kultur, dan alat yang akan digunakan dalam penanaman. Saat proses inokulasi, alat-alat dissecting set disterilisasi dengan alkohol 96\% dan dibakar dengan nyala api spiritus setiap kali akan digunakan.

\section{Inisiasi/ Penanaman}

Penanaman planlet dilakukan secara steril di laminar air flow. Planlet stroberi dorit dikeluarkan dari botol kultur yang sebelumnya. Sebelum dilakukan penanaman, planlet stroberi yang bergerombol dipisahkan menggunakan scalpel dan dibuang akarnya. Perlakuan terdiri dari 5 ulangan. sehingga seluruhnya berjumlah 20 botol dan masing-masing botol berisi 5 tanaman. Penanaman dilakukan dengan menggunakan pinset tanam steril. Kemudian ditutup rapat dengan selotip dan plastik wrap lalu diberi label. Selanjutnya diinkubasi dalam ruangan bercahaya dengan suhu $20^{\circ} \mathrm{C}$

\section{Pengamatan}

Pengamatan dilakukan setiap hari untuk melihat adanya kontaminasi, namun hasil pengamatan pada jumlah tanaman yang tumbuh akar, pertambahan jumlah daun, dan jumlah anakan diamati pada $12 \mathrm{hst}$.

\section{Analisis Data}

Analisis data digunakan untuk mengetahui kesimpulan dari hasil data yang diperoleh. Data pengamatan yang diperoleh dianalisis dengan menggunakan microsoft excel dan dibahas secara deskriptif.

\section{HASIL DAN PEMBAHASAN}

Pada pengamatan 5 hst dapat diketahui bahwa semua kultur terdapat kontaminasi bakteri. kontaminasi oleh bakteri ditandai munculnya bercak-bercak berlendir pada media atau eksplan. Bercak tersebut biasanya berwarna putih yang merupakan koloni bakteri. Bakteri lebih sulit untuk dideteksi dibandingkan dengan fungi karena dapat masuk ke dalam ruang antar sel. Kontaminasi bakteri tersebut diduga berasal dari penggunaan media yang tingkat kepadatannya masih rendah. Media yang baru dibuat, harus didiamkan lebih dari 3 hari terlebih dahulu sebelum dipakai untuk 
menanam eksplan agar tingkat kepadatannya tinggi dan tidak mudah terkena kontaminasi (Evi, 2015).

Kontaminasi bakteri tersebut ditangani dengan memberikan antibiotik pada media kultur. Dua hari kemudian, larutan antibiotik meresap kedalam media, sehingga mengakibatkan media yang awalnya berwarna abu-abu menjadi berwarna oranye namun lendir putih yang mencirikan adanya kontaminasi oleh bakteri sudah tidak ada (Gambar 1), sehingga dapat dilakukan pemindahan planlet ke media MP yang baru

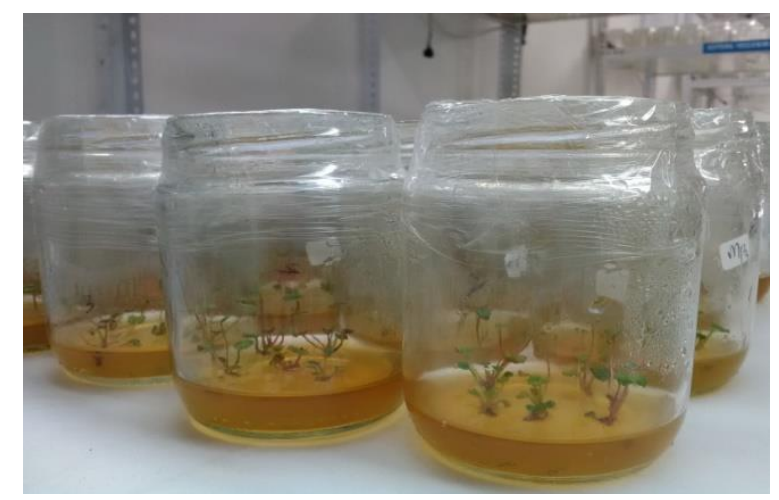

Gambar 1. Setelah 2 hari diberi antibiotik, media MP menjadi berwarna oranye

Pada 12hst, terjadi kontaminasi fungi dan gejala pencoklatan pada sebagian kultur (Gambar 2), sehinnga menyebabkan adanya planlet yang dorman dan adapula yang mati (Gambar 3). Kontaminasi fungi ditandai dengan munculnya benang-benang halus berwarna putih yang merupakan miselium fungi. Fungi dapat menginfeksi jaringan secara sistemik sehingga lama kelamaan dapat menyebabkan jaringan eksplan akan mati. Kontaminasi tersebut dapat diakibatkan oleh faktor luar yang diduga berasal dari sterilisasi yang kurang bersih, terbawa oleh sirkulasi udara dalam laminar air flow pada proses penanaman dan peralatan tanam yang kurang steril. Sterilisasi merupakan aspek yang sangat menentukan keberhasilan dalam perbanyakan tanaman melalui teknik kultur jaringan (Gunawan, 1992).

Kontaminasi adalah gangguan yang sangat umum terjadi dalam kegiatan kultur jaringan. Munculnya gangguan merupakan hal yang wajar sebagai konsekwensi penggunaan media yang diperkaya (Santoso dan Nursandi, 2003). Lebih lanjut disebutkan bahwa fenomena kontaminasi, menunjukkan semakin diperkaya suatu media maka tingkat kontaminasinya juga semakin besar, demikian pula sebaliknya. Kontaminasi merupakan salah satu faktor yang dapat mempengaruhi keberhasilan dalam kegiatan kultur jaringan.

Wattimena (1992) menyatakan bahwa jika tanaman dilukai sering terjadi penimbunan senyawa-senyawa fenolik disekitar luka seakan-akan menutup daerah luka tersebut. Santoso dan Nursandi (2003) menyebutkan bahwa pencoklatan adalah suatu karakter yang munculnya warna coklat atau hitam yang sering membuat tidak terjadinya pertumbuhan dan perkembangan tanaman kultur. Peristiwa pencoklatan sesungguhnya merupakan peristiwa alamiah biasa yang terjadi pada sistem biologi, suatu perubahan adaptif bagian tanaman akibat pengaruh fisik atau biokimia (memar, pengupasan, pemotongan, serangan penyakit atau kondisi lain yang tidak normal). 

Balai Penelitian Jeruk dan Buah Subtropika (BALIJESTRO)

\section{Pertambahan Jumlah Daun}

Jumlah dan ukuran daun dipengaruhi oleh genotipe dan lingkungan. Posisi daun

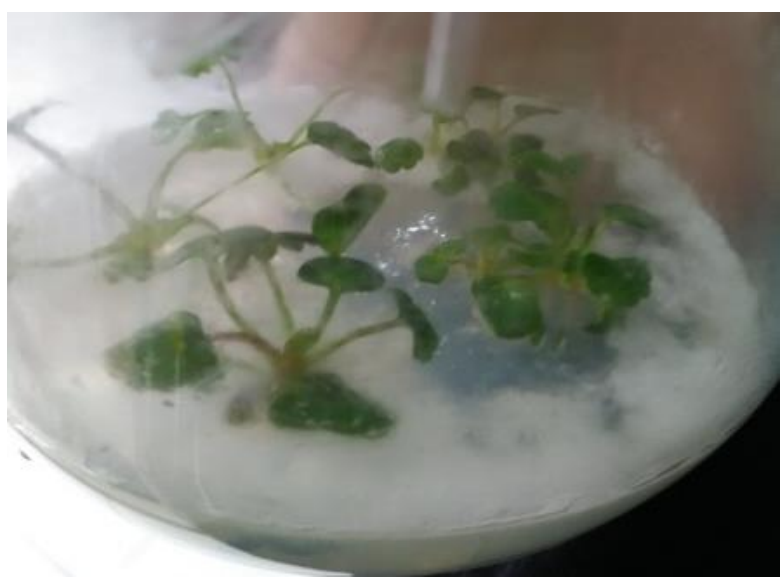

pada tanaman (jumlah plastokron), yang terutama dikendalikan oleh genotipe, juga

Gambar 2. Kontaminasi fungi (kiri) dan gejala pencoklatan (kanan) pada pangkal planlet.
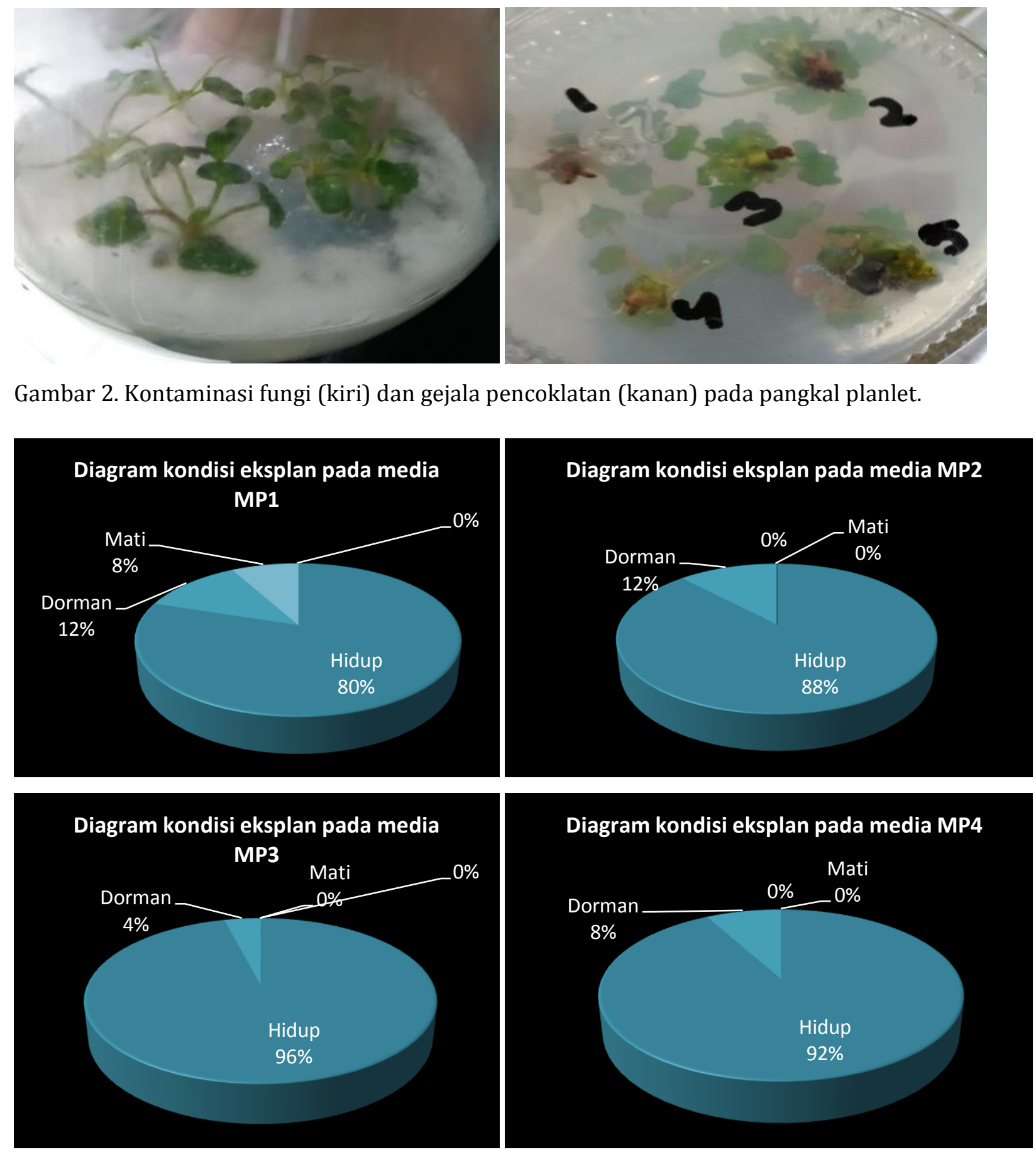

Gambar 3. Diagram presentase kondisi kultur stroberi dorit pada media MP1, MP2, MP3, dan MP4

$$
\text { mempunyai pengaruh nyata terhadap }
$$
laju pertumbuhan daun, dimensi akhir (Gardner, Pearce, Mitchell, 1991). Setiap minggunya jumlah daun mengalami perubahan, hal ini disebabkan karena terjadi kerontokan ataupun tumbuhnya daun baru 
dan ini berlaku untuk semua media. Beberapa organ tanaman mempunyai pola pertumbuhan determinate sedangkan organorgan yang lain bersifat in-determinate. Pola pertumbuhan determinate dicirikan oleh pertumbuhan organ tersebut sampai mencapai ukuran maksimal, kemudian pertumbuhan terhenti, organ menjadi tua (senescence) dan akhirnya rontok. Organ tanaman yang mempunyai pola pertumbuhan determinate salah satunya adalah daun (Lakitan, 1996).

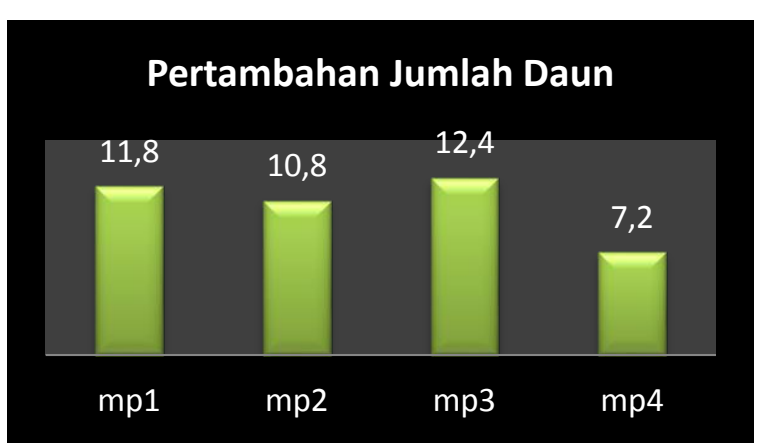

Gambar 4. Diagram yang menunjukkan pertambahan jumlah daun tanaman stroberi varietas dorit pada media MP1, MP2, MP3, dan MP4.

Gambar 4 menunjukkan bahwa pertambahan jumlah daun yang paling banyak yaitu pada tanaman stroberi dorit yang ditanam dalam media MP3 karena media tersebut mengandung kombinasi MS dan pupuk sebesar 75\% dan 25\%. Dalam media MS terkandung unsur Nitrogen yang dapat berpengaruh terhadap pertumbuhan daun. Media yang memiliki konsentrasi MS yang lebih besar, tentunya mengandung unsur nitrogen yang lebih banyak pula. Hal ini sesuai dengan teori yang kami dapat bahwa unsur hara yang paling berpengaruh terhadap pertumbuhan dan perkembangan daun adalah Nitrogen. Konsentrasi Nitrogen tinggi umumnya menghasilkan daun yang besar (Lakitan, 1996). Gardner et al (1991) menyebutkan bahwa mineral yang lain rupanya kurang berpengaruh jika dibandingkan dengan Nitrogen terhadap pertumbuhan daun.

\section{Pertumbuhan Tunas}

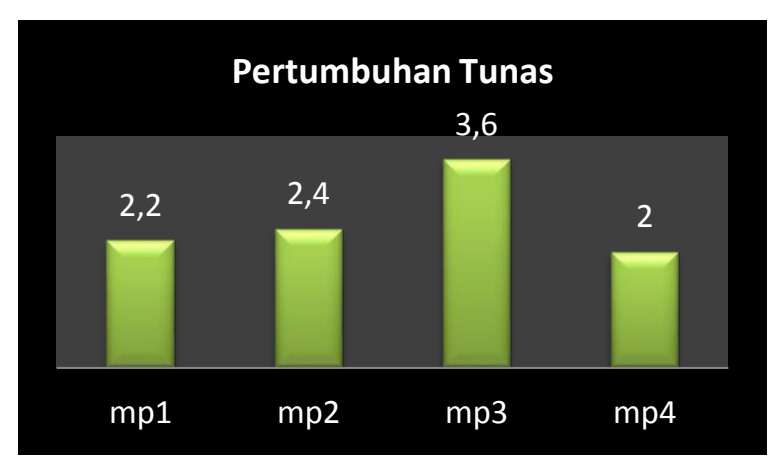

Gambar 5. Diagram yang meunjukkan pertumbuhan tunas/anakan tanaman stroberi varietas dorit pada media MP1, MP2, MP3, dan MP4.

Dapat diketahui bahwa pertumbuhan tunas paling banyak terdapat pada tanaman stroberi dorit yang ditanam pada media MP3 (Gambar 5) karena media tersebut mengandung kombinasi MS yang paling tinggi dibanding dengan MS1, MS2, dan MS3 yaitu sebesar 75\%. Nitrogen (N) dan Fosfor (P) yang terkandung dalam media MS merupakan unsur hara yang sangat dibutuhkan oleh tanaman dalam jumlah yang besar. Nitrogen merupakan anasir penting dalam pembentukan klorofil, protoplasma, protein, dan asam-asam nukleat. Unsur ini mempunyai peranan yang penting dalam pertumbuhan dan perkembangan semua jaringan hidup termasuk pertumbuhan tunas 

Balai Penelitian Jeruk dan Buah Subtropika (BALIJESTRO)

tanaman (Brady and Weil, 2002). Fosfor merupakan komponen penting penyusun senyawa untuk transfer energi (ATP dan nukleoprotein lain), untuk sistem informasi genetik (DNA dan RNA), untuk membran sel (fosfolipid), dan fosfoprotein (Gardner et al., 1991; Lambers et al, 2008).

\section{Pertumbuhan Akar}

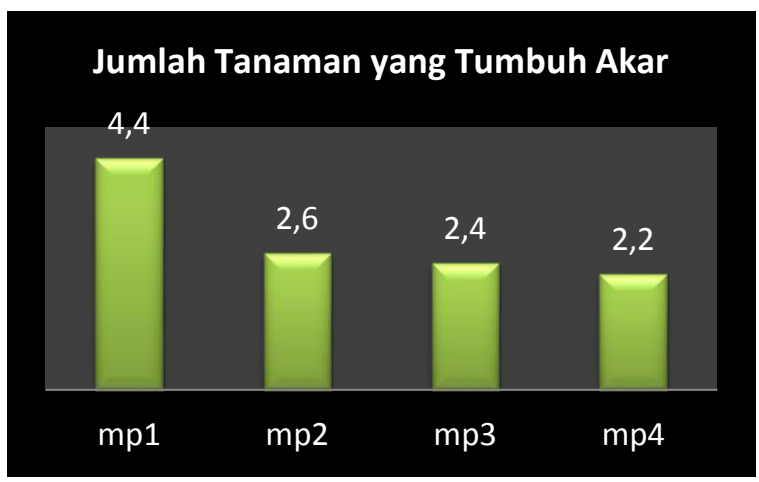

Gambar 6.. Diagram yang menunjukkan pertumbuhan akar tanaman stroberi varietas dorit pada media MP1, MP2, MP3, dan MP4.

Ketersediaan $\mathrm{N}$ dalam media tanam sangat mempengaruhi serapan tanaman terhadap $\mathrm{P}$ ataupun sebaliknya di mana ketersedian $P$ dalam media akan mempengaruhi serapan tanaman terhadap $\mathrm{N}$. Nitrogen akan meningkatkan pertumbuhan dan perkembangan akar sehingga tanaman mampu menyerap $\mathrm{P}$ lebih efektif dan selain itu $\mathrm{N}$ juga merupakan penyusun utama enzim phosphatase yang terlibat dalam proses mineralisasi P dalam media (Wanget al, 2007; Horner, 2008).

Diagram diatas menunjukkan bahwa pertumbuhan akar yang paling cepat terlihat pada tanaman di media MP1, hal ini bertentangan dengan teori yang kami dapat bahwa pertumbuhan akar dipengaruhi oleh ketersediaan unsur nitrogen yang terdapat dalam media MS. Pada media MP1, konsentrasi MS yang terkandung dalam media sangat kecil yaitu 25\%, sehingga harusnya tanaman yang lebih banyak tumbuh akar terdapat pada media MP3 yang mempunyai konsentrasi MS terbesar yaitu 75\%. Hal ini mungkin disebabkan karena adanya kontaminasi dan gejala pencoklatan pada bagian pangkal tanaman tempat tumbuhnya akar sehingga menyebabkan terganggunya pertumbuhan akar. Pencoklatan dimulai dengan munculnya warna coklat atau hitam di bagian pangkal eksplan hingga akhirnya seluruh bagian eksplan tampak berwarna coklat. Pencoklatan tersebut sering membuat pertumbuhan dan perkembangan eksplan terhambat. Bagian pangkal eksplan tersebut merupakan bagian yang mengalami pelukaan saat pengirisan eksplan. Hal ini sesuai dengan pendapat Hutami (2006), dimana pencoklatan merupakan peristiwa alamiah yang bisa terjadi pada sistem biologi, yaitu proses perubahan adaptif bagian tanaman akibat pengaruh fisik dan biokimia. Proses pencoklatan juga sering terjadi karena rangsangan kimia, seperti aktivitas enzim pengoksidasi yang mengandung tembaga $(\mathrm{Cu} 2+)$ seperti polifenol oksidase dan tirosinase (Lerch, 1981). Polifenol oksidase mengkatalisis reaksi oksidasi yang menggunakan molekul oksigen sebagai cosubstrat. Reaksi ini tidak hanya tergantung pada adanya oksigen, tetapi juga pada $\mathrm{pH}$. 
Santoso dan Fatimah (2001) menyatakan bahwa enzim polifenol oksidase optimalnya pada pH 6,5 dan menurun seirama dengan turunnya pH. Reaksi oksidase tidak akan berlangsung pada $\mathrm{pH}$ rendah. Hal inilah yang menyebabkan pada saat pembuatan media kultur harus dikondisikan pada $\mathrm{pH}$ 5,8.

Proses pencoklatan menurut George dan Sherrington (1984) dapat ditanggulangi dengan beberapa cara, antara lain: menghilangkan senyawa fenolik, memodifikasi potensial redoks, menghambat aktivasi enzim fenol oksidase, serta menurunkan aktivitas fenolase dan ketersediaan substrat. Senyawa fenol dapat dikurangi dengan melakukan pencucian. Eksplan yang diisolasi dapat direndam dalam air steril selama 2-3 jam sebelum ditanam pada medium. Selain itu, solusi untuk mengurangi pencokelatan dapat menggunakan arang aktif, cysteine, asam askorbat, PVP (polyvinylpyrrolidone), dan silver nitrate (Dwipayana, dkk., 2016).

\section{KESIMPULAN}

Berdasarkan percobaan yang telah dilakukan dapat disimpulkan bahwa pertumbuhan tanaman stroberi (Fragaria ananassa Duch.) varietas dorit yang ditanam pada media MP yang berbeda menunjukkan perbedaan yang signifikan pada pertumbuhan akar, pertumbuhan tunas dan pertambahan jumlah daun. Jenis variasi media MP yang sesuai dan menghasilkan respon pertumbuhan paling cepat yaitu media MP3 karena mempunyai konsentrasi larutan MS lebih banyak yaitu 75\% dibandingkan yang lain, sehingga sumber nitrogen yang dibutuhkan lebih tercukupi.

\section{DAFTAR PUSTAKA}

A. M. Shohael. 2008. Advantages of Plant Tissue Culture. JSPS Fellow at Gene Research Center Tsukuba University. Japan.

A. Mozafari, M. Gerdakaneh. 2012. "Influence of Media and Growth Regulators on Regeneration and Morphological Characteristics of Strawberry cvs Kurdistan and Merck (Fragaria $\mathrm{x}$ ananassa Duch.). ", International Journal of Plant Physiology and Biochemistry 4(5) 99-104.

Anonim, 2012, Materi 2. "Ekstraksi dan Pengeringan Benih". Universitas Brawijaya. Malang.

Badan Pusat Statistik. 2011 "Perkembangan Beberapa Indikator Utama SosialEkonomi Indonesia." Katalog BPS: 3101015.

Budiman, S. dan D. Saraswati. 2006. Berkebun Stroberi Secara Komersil. Seri Agribisnis. Penebar Swadaya, Jakarta. Hal:7-33

Darrow, GM. 1999. "The Strawberry: History, breeding and physiology, The strawberry from Chile", http://www.nal.usda.gov/pgdic/Str awberry (diakses pada 2 Februari 2017).

Dwipayana, Gusti Arya Jelantik. Hestin Yuswanti dan Ida Ayu Mayun. 2016. Induksi Kalus Stroberi (Fragaria Spp.) Melalui Aplikasi Asam 2,4Diklorofenoksiasetat Secara In Vitro. E-Jurnal Agroekoteknologi Tropika. Vol. 5, No. 3: 310-321 
E. Iszak, and S. Izhar. 1992. "Strawberry Plant Dorit", State of Israel Ministry of Agriculture. Israel.

Gunawan, L.W. 1987. Teknik Kultur Jaringan Tumbuhan. PAU Bioteknologi IPB. Bogor.

Gunawan, LW 1996, Stroberi. Penebar Swadaya. Jakarta.

Hancock, JF. 1999. "Strawberries". Crop Production Science in Holticulture. CABI Publishing. USA.

Hanif, Z. dan Ashari, H. 2015. Sebaran Stroberi (Fragaria $x$ ananassa) di Indonesia. Balitjestro. Batu Malang.

Hannum, SM. 2004. 'Potential impact of strawberries on human health', Crit. Rev. Food Sci. Nutr. 44: 1-17.

Henuhili, victoria. 2013. Kultur Jaringan Tanaman. Fakultas MIPA UNY. Yogyakarta.

ISTA. 2000. "International Rules for Seed Testing: Rules 2000". Seed Science and Technology, 13 (2) : 299 - 355.

J.R.P. Katuuk. 1989. "Teknik Kultur Jaringan dalam Mikropropagasi Tanaman", Jakarta DEPDIKBUD, Direktorat Jenderal Pendidikan Tinggi pengembangan Lembaga Pendidikan Tenaga Kependidikan.

Marlina, Nina. 2004. Teknik Modifikasi Media Murashige and Skoog (MS) untuk Konsentrasi In Vitro Mawar (Rossa sp.). Buletin Teknik Pertanian. Balai Penelitian Tanaman Hias, Cianjur. Vol. 9, Nomor 1.

Mutmainah, Siti. 2016. Induksi Tunas Adventif Bawang Putih Tunggal (Allium sativum) dengan Penambahan BAP dan NAA Secara In Vitro. Skripsi. Jurusan Biologi, Fakultas Sains dan Teknologi, Universitas Islam Negeri Maulana Malik Ibrahim. Malang.
Nursyamsi. 2010. Teknik kultur jaringan sebagai alternatif Perbanyakan Tanaman untuk Mendukung Rehabilitasi Lahan. Balai Penelitian Kehutanan. Makassar.

Santoso, U dan F. Nursandi. 2003. Kultur Jaringan Tanaman. Universitas Muhammadiyah Malang. Malang.

Semendaya, Fauzan hidayatulloh. 2014. Kultur Jaringan Stroberi (Fragaria sp.) di Balai Penelitian Tanaman Jeruk dan Buah Subtropika Batu Jawa Timur. Teknologi Industri Benih, IPB. Bogor.

Soemadi, W. 1997. Budidaya Stroberi di Pot Dan Kebun. CV. Aneka, solo.

Sukumalanandana, C \& Verheij, EWM. 1997, Fragaria $x$ ananassa (Duchesne). In E.W.M. Verheij and R.E. Coronel (Eds.). Edible Fruits and Nuts. Prosea Plant Resources of SouthEast Asia. Bogor, Indonesia

Tohir, KA. 1978. Bercocok Tanam Pohon Buahbuahan. Pradnya Paramitha. Jakarta.

Wareing, P.F. and I.D.J. Phillips. 1976. The Control of Growth and Differentiation in Plants. Pergamon Press. New York-Sidney-Paris-Frankfurt.

Wattimena, G. A. 1992. Zat Pengatur Tumbuh Tanaman. Pusat antar Universitas Institut Pertanian Bogor. Bogor.

Zebrowska, Jl 2004, 'Micropopagation in the strawberry (Fragaria $x$ ananassa Duch.) inbred lines', Food, Ag. \& Environ., vol. 2, pp. 253-55. 